\title{
Endocrinology of Adipose Tissue - An Update
}

Authors

Affiliations

\section{P. Fischer-Posovszky ${ }^{1}$, M. Wabitsch ${ }^{1}$, Z. Hochberg ${ }^{2}$}

${ }^{1}$ Division of Pediatric Endocrinology and Diabetes, Department of Pediatrics and Adolescent Medicine, University of Ulm, Ulm, Germany

${ }^{2}$ Meyer Children's Hospital, Rambam Medical Center, and Faculty of Medicine, Technion-Israel Institute of Technology, Haifa, Israel

Key words
obesity
adipocyte
fat cell
SGBS cells
adiponectin
leptin
visfatin
RBP-4

received 8.1 .2007

accepted 14.2.2007

Bibliography

DOI 10.1055/s-2007-976539

Horm Metab Res 2007;

39: 314-321

(c) Georg Thieme Verlag KC

Stuttgart · New York .

ISSN 0018-5043

\section{Correspondence}

Prof. Dr. M. Wabitsch

Division of Pediatric Endocrinology and Diabetes

Department of Pediatrics and

Adolescent Medicine

University of Ulm

Eythstr 24

$89075 \mathrm{Ulm}$. Germany

Tel.: +49/731/5002 7715

Fax: +49/731/50026714

martin.wabitsch@uniklinik-

ulm.de

\section{Abstract \\ $\nabla$}

Adipose tissue is the body's largest repository of energy and it plays an important role in total energy homeostasis. Moreover, it is now well recognized as an endocrine organ. A wide range of different factors including complex proteins as well as fatty acids, prostaglandins, and steroids are either synthesized de novo or converted

\section{Introduction}

$\nabla$

For many years, adipose tissue was considered as a passive organ playing a metabolic role in total energy homeostasis. Its only function was believed to be the storage of excess energy as triglycerides, and its release according to need in the form of fatty acids.

Now, there has been a paradigm shift and it becomes increasingly clear that adipose tissue is an endocrine organ secreting a wide range of hormones and other factors [1,2]. These so-called adipokines contribute to the development of obesity-related disorders, particularly type-2 diabetes (T2D) and cardiovascular disease. Thereby, adipose tissue itself participates in the pathogenesis of obesity-associated co-morbidities [1, 2, 3].

In 2002, Hormone and Metabolic Research published a special issue on The Endocrinology of Adipose Tissue (Editorial [4],). It summarized the 20th century understanding of the hormonal cross-talk between fat cells and many other tissues such as endothelium, muscle, liver, pancreas, adrenal glands, and central nervous structures. A central message in that issue was that obesity represents a state of chronic inflammation, which may act as common soil for the development of insulin resistance and cardiovascular dysfunction. By then scientists had only preliminary data on the effects of dietary meas- in adipose tissue and released into the blood stream. These so-called adipokines contribute to the development of obesity-related disorders, particularly type-2 diabetes (T2D) and cardiovascular disease. In this review, we present an overview on the endocrine functions of adipose tissue with a special focus on discoveries reported within the past 5 years.

ures and of specific drugs that may be able to restore the dysregulated endocrine system of adipose tissue. It was hoped that through prevention and intervention the deleterious sequelae of obesity and, in particular, of the visceral accumulation of body fat, might be avoided.

Five years later, more than one hundred adipose tissue secretion products have been described including fatty acids, prostaglandins, and steroids, as well as complex proteins ( $\bullet$ Fig. 1). Some of these factors primarily have local auto- or paracrine effects in adipose tissue, while others are released into the circulation and exert specific effects at target organs or systemic effects. In this review, we present an overview of the endocrine functions of adipose tissue with special focus on findings obtained within the past 5 years.

\section{Old and new findings of adipose tissue cellularity $\nabla$}

Adipose tissue mass is determined by competing processes regulating both the volume and the number of adipocytes. For many years the dogma claimed that the number of adipocytes is fixed during childhood, and remains constant throughout life. According to this model, changes in size of adipose tissue could only be achieved by modulation of adipocyte volume, which in turn is bal- 


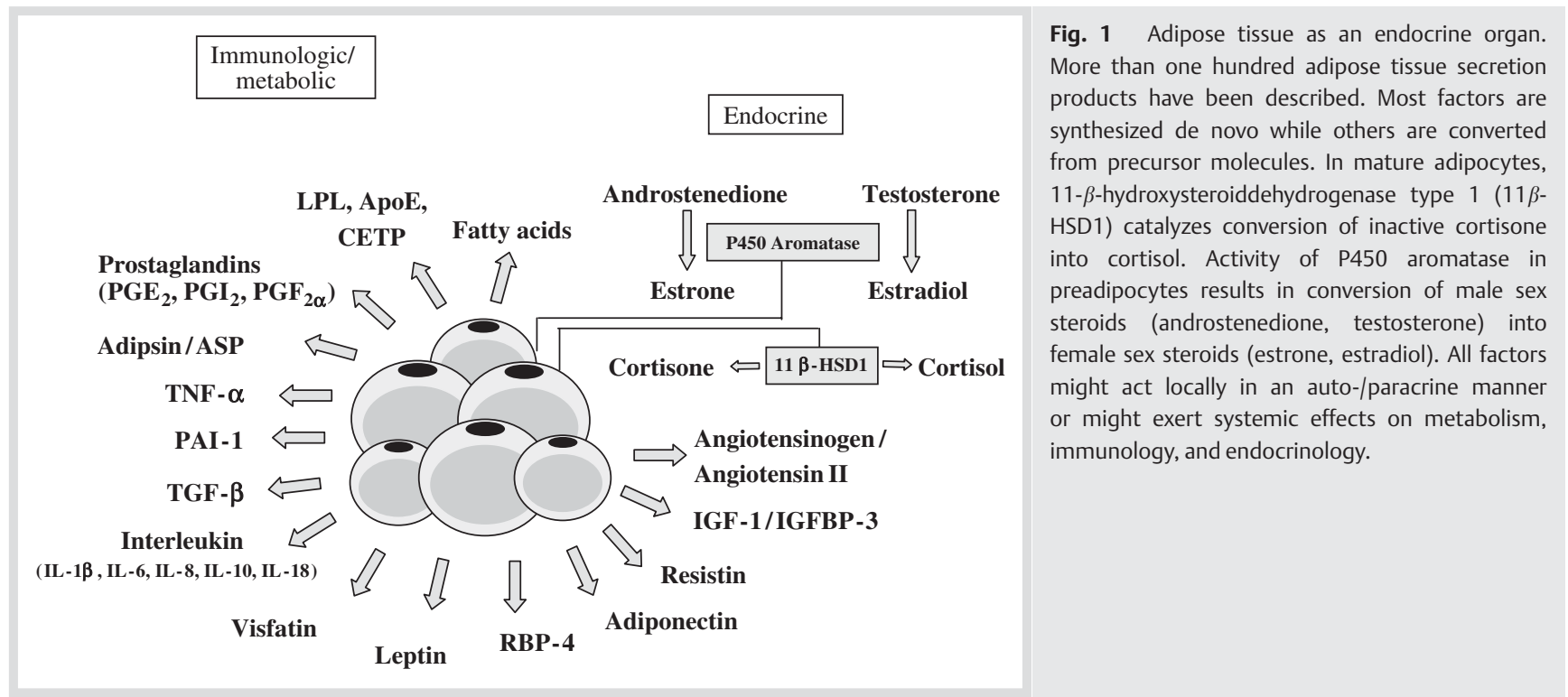

anced by storage of triglycerides (lipogenesis) and mobilization of fatty acids (lipolysis).

This model does not hold true any longer. In addition to changes in adipocyte volume, modulations of adipocyte number have been shown to occur throughout life $[5,6,7,8,9]$. Adipose tissue contains a large pool of precursor cells - multipotent mesenchymal stem cells and pre-determined preadipocytes - which are available for proliferation and differentiation into mature adipocytes upon appropriate stimulation [10]. These precursors can be detected in adipose tissue at all stages of life [9]. A reduction of adipocyte number can be achieved by a de-lipidation and dedifferentiation of adipocytes [11]. On the other hand, there is now growing evidence that apoptosis of fat cells occurs in adipose tissue $[6,7,8]$. Therapeutically, an enhancement of adipocyte apoptosis during weight loss would be beneficial since the post-obese state is characterized by vulnerability of the adipose tissue for hyperplasia, associated with lower leptin production - a relative hypoleptinemia [12].

Thus, obesity is characterized by an enlargement of adipose mass by either fat cell hypertrophy or, in severe forms, by a combination of hypertrophy and hyperplasia [13]. Initially, an increase in body weight leads to hypertrophy of existing adipocytes. Once these cells exceed a critical cell size, unknown factors trigger the differentiation of precursor cells into mature adipocytes. Recent findings show that cell size seems to be critical for fat cell function $[14,15]$. Thus, large fat cells are less sensitive to the metabolic effects of insulin and exert a higher basal rate of lipolysis in comparison to smaller fat cells [16]. Interestingly, there is also a marked difference in gene expression between small and large human adipocytes [17].

Besides mature, lipid-laden adipocytes and precursor cells, adipose tissue contains endothelial cells, nerve cells, and immune cells [5]. The latter are of special interest since it has become apparent that inflammation may underlie the development of obesity-related disorders. The existence of an inflammatory state of adipose tissue was proposed for the first time by Hotamisligil et al., [18] who showed constitutive production of TNF- $\alpha$ (tumor necrosis factor- $\alpha$ ) by white adipose tissue. Recently, it has been shown that obesity is associated with macrophage accumulation in white adipose tissue $[19,20,21,22]$. The abundance of macrophages in the adipose tissue is positively correlated with increased BMI (body mass index) [19,22], and it has been shown that these macrophages significantly contribute to the secretion of pro-inflammatory cytokines from adipose tissue. At the clinical level, obese subjects show high serum levels of pro-inflammatory adipokines and reactive proteins, which are reversed by weight loss [23]. Thus, the so-called adipokines include not only adipocyte-specific factors but also secretion products derived from other cells types found in adipose tissue, such as preadipocytes or macrophages.

\section{Recently discovered important adipokines \\ $\nabla$}

Leptin

The identification of the leptin gene [24] and its cognate receptor $[25,26,27]$ started the endocrine era of the adipocyte. Mice with mutations in the leptin gene (ob/ob mice) [24] or the leptin receptor gene ( $d b / d b$ mice) $[25,26,27]$ are massively obese. These data have been extensively reviewed by Campfield et al. [131] in a special issue of Hormone Metabolic Research in 1996. Like in mice, congenital leptin deficiency in humans causes severe obesity, impaired thermogenesis, and insulin resistance; all are reversed by leptin treatment [28]. Although leptin was first regarded as a promising anti-obesity drug, administration of recombinant leptin to overweight and obese subjects was not efficacious in terms of weight loss [29] due to central leptin resistance. Potential mechanisms for leptin resistance have been proposed and include defective transport of leptin across the blood-brain barrier, defects in leptin signaling and central antagonism of leptin physiological actions. In that respect, Socs3 was reported to be a molecular mediator of leptin resistance, suggesting that strategies to lower or inhibit the action of Socs3 may be of value in the prevention and treatment of human obesity and associated insulin resistance $[30,31]$.

Besides its role in regulation of body weight, leptin regulates puberty and reproduction, placental and fetal function, immune response, and insulin sensitivity of muscle and liver. In hypoleptinemic patients with lipodystrophy, leptin replacement therapy resulted in a dramatic improvement in glucose metabolism, dyslipidemia, and hepatic steatosis [32]. An overview on the various 
effects of the hormone has been given in a number of recent reviews [33, 34, 35].

Bouret et al. described an unanticipated regulatory role of leptin - that of a neurotrophic growth factor during development of the hypothalamus [36]. Leptin promotes formation of hypothalamic pathways that later convey leptin signals to brain regions regulating food intake and energy consumption. These observations are consistent with the concept that under- and over-nutrition during critical periods of hypothalamic development may induce long-lasting and potentially irreversible effects into adulthood.

\section{Adiponectin}

Adipoenectin, also referred to as Acrp30 [37], AdipoQ [38], apM1 [39], or GBP28 [40], was first identified by four independent groups using different approaches. It is specifically expressed in mature adipocytes with higher levels detected in subcutaneous rather than visceral fat [41]. It is released into the blood stream and accounts for $\sim 0.01 \%$ of all serum proteins [42]. Adiponectin is a $30 \mathrm{kDa}$ protein with an $\mathrm{N}$-terminal collagen-like domain and a C-terminal globular domain. As such it structurally belongs to the collagen superfamily, which is known to form characteristic multimers [43, 44, 45]. Indeed, after posttranslational modification by glycosylation and hydroxylation [46] it creates, via its collagen domain, 3 major oligomeric forms: a low molecular weight (LMW) trimer, a middle molecular weight (MMW) hexamer, and a high molecular weight (HMW) 12-18-mer [47,48]. In addition, a smaller, globular fragment of adiponectin has been detected, which accounts for $\sim 1 \%$ of total circulating adiponec$\operatorname{tin}[49,50]$.

Two receptors for adiponectin, AdipoR1 and AdipoR2 have been cloned [51]. Both contain seven-transmembrane domains, but are functionally and structurally different from $G$ protein-coupled receptors [51]. AdipoR1 is expressed in muscle and binds with high affinity to globular adiponectin and with low affinity to full-length adiponectin. AdipoR2 is expressed primarily in liver and binds full-length adiponectin and, with relatively low affinity, the globular form. Thus, the biological effects of adiponectin not only depend on relative circulating concentrations, but also on tissue-specific expression of its receptor subtypes.

In contrast to other adipokines, serum adiponectin is reduced with obesity, under conditions of insulin resistance and T2D, and cardiovascular disease in correlation with increasing severity [52,53]. This reduction seems to precede the disorders [54]. Low levels of adiponectin, especially the HMW form, apparently predict the development of T2D and cardiovascular disease [55, $56,57,58,59]$. In addition, a close correlation of adiponectin levels has been shown with risk factors and components of the metabolic syndrome [53]. Weight loss results in an increase in adiponectin levels that is accompanied by an improvement in insulin sensitivity [53]. These findings demonstrate the important role of adiponectin in the pathogenesis of the metabolic syndrome. It is further supported by adiponectin gene polymorphisms, which may result in hypoadiponectinemia, insulin resistance, T2D, and cardiovascular disease $[60,61]$.

Numerous experimental studies have been performed investigating the effect of adiponectin and the underlying molecular mechanisms in several in vitro and in vivo models, as recently reviewed [49,62]. An insulin-sensitizing effect of adiponectin was first identified by three independent groups in 2001 $[50,63,64]$. Many subsequent studies rounded up a large picture of adiponectin action in different tissues, as reviewed [49].
Globular, trimeric adiponectin or the HMW multimer binds to AdipoR1, which in turn stimulates interaction of the N-terminal cytoplasmic domain with an intracellular adaptor protein (APPL), containing a pleckstrin homology domain, phosphotyrosinebinding domain, and leucine zipper motif [65]. AdipoR2 is mainly activated by multimers of full-length adiponectin. Binding of adiponectin to its receptors causes activation of specific intracellular pathways, which include p38 MAPK, AMPK, and $\operatorname{PPAR} \alpha$. Subsequently, this leads to a reduction of plasma glucose levels by an increased glucose uptake and increased fatty acid oxidation in muscle, where AdipoR1 is predominantly expressed, and by increased fatty acid oxidation and decreased gluconeogenesis in liver.

As another beneficial aspect, adiponectin has been reported to exert antiatherosclerotic effects. It downregulates the expression of the vascular adhesion molecules: intracellular adhesion molecule-1, vascular cellular adhesion molecule-1, and E-selectin [66]. It inhibits endothelial $\mathrm{NF} \kappa \mathrm{B}$ signaling which might be a major mechanism for inhibiting monocyte adhesion to the vascular wall $[67,68]$. Besides reduction of scavenger receptor class A-1 expression in macrophages [69], adiponectin inhibits proliferation and migration of smooth muscle cells [70].

Several findings suggest that adiponectin plays also an important role in innate and adaptive immunity [71]. It induces the production of important inflammatory cytokines, such as IL-10 and IL-10 receptor antagonist (IL-10 RA) by human monocytes, macrophages, and dentritic cells, and inhibits the generation of interferon- $\gamma$ by lipopolysaccharide (LPS) stimulated macrophages [72]. Adiponectin suppresses Toll-like receptor (TLR)induced activation of $\mathrm{NF}_{\kappa} \mathrm{B}$ [73]. It markedly reduces the phagocytic capacity of macrophages, decreased T-cell responses [72], and influences B-cell lymphopoesis [74]. Taken together, these observations make adiponectin an important suppressor of inflammation, linking the paradoxical decrease of adiponectin levels in obesity to associated diseases such as insulin resistance, T2D, and atherosclerosis.

\section{Retinol binding protein 4 (RBP4)}

In 2001, Abel et al. postulated the existence of an adipocytesecreted factor that cause insulin resistance when they found that mice with an adipose-specific GLUT4 knockout developed insulin resistance in muscle and liver [75]. On the other hand, mice specifically overexpressing GLUT4 in adipose tissue exhibited an increased efficiency of glucose clearance [76]. DNA arrays of these two mice identified RBP4 [77]. RBP4 is a specific circulating transport protein for retinol (Vitamin A) [78]. RBP4 was upregulated in adipose tissue of adipose-Glut4 ${ }^{-/-}$mice, and its serum levels were elevated in five independent mouse models of obesity and insulin resistance. Treatment with the insulin sensitizing PPAR $\gamma$ agonist rosiglitazone lowered RBP4 levels and normalized insulin sensitivity in mice lacking GLUT4, and injection of recombinant RBP4 to normal mice, or overexpression of RBP4, induced insulin resistance. On the other hand, mice with a heterozygous or homozygous RBP4 knockout showed increased insulin sensitivity. Most promising, fenretinide, a synthetic retinoid that is currently in trials as an antineoplastic agent, enhanced the urinary excretion of RBP4, lowered serum RBP4 in mice on a high-fat diet and markedly improved insulin sensitivity [77]. The expression of GLUT4 is greatly reduced in adipocytes but not in muscle cells of obese and insulin resistant mice and humans [79]. The recent study by Yang et al. suggests that adipose tissue might act as a glucose sensor: adipocytes detect the 
absence of glucose by GLUT4 and respond by secreting RBP4. The latter inhibits insulin signaling by decreasing PI-3 kinase activity and insulin receptor substrate-1 (IRS-1) phosphorylation in muscle, while expression of the gluconeogenic enzyme phosphoenolpyruvate carboxykinase (PEPCK) is upregulated in the liver [77]. Consequently, this might cause an increase in circulating blood glucose. Intensive research on the regulation of RBP4 secretion is necessary to support this interesting but still hypothetical model.

In human subjects retinol levels are elevated in patients with T2D $[80,81]$. A current genetic study has identified an SNP in the RBP4 gene that is associated with T2D in Mongolians [82]. RBP4 levels correlated with the magnitude of insulin resistance among humans with obesity, impaired glucose tolerance, or T2D and among nonobese nondiabetic subjects with a strong family history of T2D [83]. A confirmatory report showed that plasma RBP4 concentrations were higher in impaired glucose tolerance (IGT) and T2D [84], and elevated serum RBP4 was associated with components of the metabolic syndrome, including increased BMI, waist-to-hip ratio, serum triglyceride levels, systolic blood pressure and decreased high-density lipoprotein (HDL) cholesterol [83]. An association of exercise training with reduction of serum RBP4 was only observed in subjects with improved insulin resistance [83].

The observations concerning BMI are, however, controversial since two other groups found no correlation of serum RBP4 with BMI [85] or percentage of body fat [84]. Moreover, Janke et al. did not see a relationship between adipose tissue mRNA expression and serum RBP4, which led them to suggest that an increase in systemic RBP4 in insulin-resistant subjects could not be explained by increased RBP4 production in adipose tissue [85]. The same study found a reduced expression of GLUT4 in overweight or obese subjects, but a robust positive correlation between adipose GLUT4 and RBP4 expression that was completely independent of any other confounding variable, including BMI [85].

Despite all controversy, RBP4 represents a curious new adipokine in mice and humans. Further studies will help understanding its role in the pathogenesis of obesity-related disorders and show whether RBP4 might serve as a potential therapeutic target for the treatment of T2D.

\section{Visfatin}

Searching for genes which are specifically expressed in visceral adipose tissue by differential display, Fukuhara et al. [86] reported that pre-B cell colony enhancing factor (PBEF) is highly expressed in human visceral fat. PBEF was originally cloned and characterized as a $52 \mathrm{kDa}$ protein primarily expressed in bone marrow, liver, and muscle [87]. For years, it was considered a secreted cytokine whose levels increase during infection [88]. Rongvaux et al. proposed that the protein is a nicotinamide phosphoribosyltransferase [89], which was confirmed recently after determining its crystal structure [90].

PBEF was further referred to as "visfatin" [86], because protein levels were increased in visceral adipose tissue of a mouse model for obese T2D, and correlated with visceral fat area (but not subcutaneous fat area) in human subjects. Visfatin was upregulated during adipogenic differentiation, and plasma levels increased during the development of obesity. Visfatin exerts insulinmimetic effects in cultured cells, i.e., stimulation of glucose uptake and triglyceride incorporation, and intravenous injection of recombinant visfatin to mice lowered plasma glucose within
30 minutes. This effect was accompanied by an increased expression of genes involved in adipogenesis, increased phosphorylation of IRS- 1 and IRS- 2 in liver, and activation of insulin signaling. Mice heterozygous for a targeted mutation in the visfatin gene had modestly higher levels of plasma glucose in comparison to wild-type littermates. The most intriguing finding was that visfatin binds to and activates the insulin receptor. Further investigations revealed that visfatin binds to the insulin receptor at a site distinct from insulin and with an affinity similar to insulin [86]. The insulin sensitizing effect of visfatin seems to be additive to the effect of insulin suggesting that visfatin may activate insulin-regulated pathways via a novel mechanism.

The original paper stimulated many groups to study the biology of visfatin, and several factors regulating visfatin synthesis have been identified. In 3T3-L1 adipocytes, TNF- $\alpha$, IL-6, growth hormone, and $\beta$-adrenergic receptor agonists inhibited visfatin synthesis, while glucocorticoids had an opposite effect [91,92]. Studies in transgenic mice and humans have shown that cortisol might be locally synthesized from inactive cortisone by $11 \beta$ hydroxysteroiddehydrogenase type 1 (11 $\beta$-HSD1) in visceral adipose tissue $[93,94]$. Thus, glucocorticoids might contribute to the upregulation of visfatin found in visceral obesity in vivo [86]. In 3T3-L1 cells, the PPAR $\gamma$ agonist troglitazone suppressed visfatin gene expression [92]. In contrast, treatment with rosiglitazone in healthy human subjects and incubation of isolated human adipocytes with rosiglitazone increased plasma visfatin expression and its secretion into the medium, respectively [95]. It has been shown that circulating visfatin concentrations are increased by hyperglycemia in healthy subjects and that this effect was blocked by exogenous hyperinsulinemia or somatostatin infusion [96].

The work of Fukuhara et al. also stimulated many groups to evaluate visfatin in their well characterized group of patients. In line with the original paper, some groups found elevated visfatin levels in patients with T2D [97, 98, 99]. Controversial results were found regarding a correlation of visfatin with the degree of obesity $[97,98,99,100,101,102]$. Haider et al. detected elevated visfatin concentrations in patients with T1D, which were lowered by exercise [103]. Weight loss after gastric banding lowered increased plasma visfatin concentrations in morbidly obese patients [102]. Genetic studies have revealed that variations in the visfatin gene might have a minor effect on its mRNA regulation, but do not play a major role in the development of T2D [104].

Several open questions remain unanswered. It is not clear whether visfatin is regulated by thiazolidindiones. In 3T3-L1 cells, troglitazone lowered visfatin mRNA expression [92], while it was upregulated in isolated human adipocytes [95]. In patients with T2D, a 4-week treatment with rosiglitazone did not change plasma visfatin concentration [99]. It is controversial whether visfatin is differentially regulated in subcutaneous and visceral adipose tissue $[100,101]$. An interesting twist suggested recently that visfatin is an inflammatory protein, and is predominantly secreted by macrophages [105].

In conclusion, visfatin has recently been identified as a new adipokine. Its role in the modulation of whole body insulin sensitivity and its contribution to the pathogenesis of insulin resistance still needs to be addressed carefully.

\section{Angiotensinogen (ANG)/Angiotensin II (ANG II)}

Adipose tissue is an important site of angiotensinogen or angiotensin II production. Higher levels of angiotensinogen mRNA 
levels are detectable in adipose tissue of obese subjects in comparison to lean subjects [106]. In addition, a positive association of BMI and circulating concentrations of angiotensinogen has been found in a clinical study [107]. Angiotensin II is a very potent vasoconstrictor and the risk for hypertension increases with BMI. Thus, it has been assumed that an increased synthesis of angiotensin II by adipose tissue might contribute to obesityassociated hypertension. In fact, overexpression of AGT in adipose tissue in mice resulted in elevated plasma AGT and hypertension [108]. In addition, ANG II seems to exert different pro-inflammatory effects locally in adipose tissue. ANG II stimulates production and secretion of PAI-1, leptin, IL-6 and IL8 in cultivated human adipocytes which can be abolished by blocking of angiotensin-receptor subtype 1 [AT(1)] [109, 110, 111]. In addition, ANG II increases oxidative stress and activates $\mathrm{NF}_{\kappa} \mathrm{B}$ as well as $\mathrm{NAD}(\mathrm{P}) \mathrm{H}$ oxidase $[112,113]$.

The clinical relevance of all these findings is still not completely understood. However, in summary all these effects might help understand why lowering ANG II production by angiotensinconverting enzyme inhibitors (ACEIs) and AT(1) receptor blockade leads to improvement of chronic inflammation in practice $[112,113,114]$.

\section{Proinflammatory cytokines}

Adipose tissue produces a plethora of other factors which have their origin from either mature adipocytes or other cell types. Pro-inflammatory cytokines are coming to the fore, since obesity has been recognized as a state of low-grade inflammation, and adipose tissue has been accepted as a pathogenic site of obesity-related disorders [115].

In 1993, Hotamisligil et al. [18] showed an increased expression of TNF- $\alpha$ in adipose tissue of genetically obese rats. The idea that a factor produced from white adipose tissue is involved in the development of insulin resistance was revolutionary at that time. Since then, many other factors were described to be secreted from adipose tissue, including transforming growth factor- $\beta$ (TGF- $\beta$ ), interferon- $\gamma$ (IFN- $\gamma$ ), interleukins (IL), such as IL-1, IL-6, IL-10, and IL-8, monocyte chemotactic protein1 (MCP-1), and factors of the complement cascade (complement factor 3, metallothionein, angiopoietin-related proteins, plaminogen activator inihibitor-1, fibrinogen) [116, 117, 118, 119, 120].

The circulating levels of these pro-inflammatory factors increase with the enlargement of fat mass. Many of these pro-inflammatory factors are produced by adipocytes and also by activated macrophages. The relative amount of each remains unknown so far. The increase of cytokines together with the finding that obesity is associated with macrophage infiltration in adipose tissue suggests that obesity should be considered as a state of low-grade inflammation.

Indeed, it has been shown that increasing adiposity activates two typical pro-inflammatory pathways, c-jun $\mathrm{NH}_{2}$-terminal kinase (JNK) and IkappaB kinase- $\beta$ (IKK- $\beta)[121,122,123,124]$. Concordantly, chemical or genetic inhibition of JNK or IKK$\beta / \mathrm{NF} \kappa \mathrm{B}$ (nuclear factor-kappa $\beta$ ) improves insulin resistance. Several mechanisms have been hypothesized to explain how obesity activates these receptor pathways [TNF receptor, IL-1 receptor, TLR, receptor for advanced glycation end products (RAGE)] and receptor-independent pathways (for example reactive oxygen species, endoplasmatic reticulum stress) [125]. Obesity induced IKK- $\beta$ activation results in $\mathrm{NF} \kappa \mathrm{B}$ translocation to the nucleus and to increased expression of potential mediators that could cause insulin resistance. Obesity-induced JNK activa- tion, on the other hand, promotes phosphorylation of IRS-2, which in turn prevents normal insulin signal transduction.

The initial events of how obesity might activate inflammation in adipose tissue are not completely understood. One potential mechanism involves the initiation of a state of cellular stress by dietary excess and excess lipid accumulation in adipose tissue.

\section{Wnt signaling}

The Wnt family of secreted signaling molecules has profound effects on diverse developmental processes, including the fate of mesenchymal progenitors. Activation of Wnt signaling inhibits adipogenesis [126]. Thus, transgenic mice in which Wnt10b is expressed from the FABP4 promoter show impaired development of adipose tissue and a decline of total body fat [127, 128]. Consistently, a non-functioning WNT10B allele was detected in a family affected by obesity [129].

Recently, Gustafson et al. have shown that IL- 6 and TNF- $\alpha$ augmented Wnt signaling in 3T3-L1 preadipocytes thereby preventing adipogenic differentiation and lipid accumulation [130]. Both cytokines increased the expression of inflammatory genes in 3T3-L1 adipocytes [130]. The authors concluded that these findings might help understand the development of local and systemic inflammation as well as ectopic lipid accumulation in obesity.

\section{Concluding remarks}

$\nabla$

Endocrinology of adipose tissue remains an exciting research area in which epoch-making findings are still expected. The recently discovered new functions of adipose tissue have elucidated its important role in a complex cross-talk between organs regulating the body's energy homeostasis, insulin sensitivity, lipid metabolism, and the immune system. Thus, adipose tissue and its secretion products have also become a target for drug development. Improved knowledge on the endocrinology of adipose tissue will have implications for the treatment of obesity, diabetes, and cardiovascular diseases.

\section{Acknowledgments}

$\nabla$

The authors acknowledge the funding by the German Research Association (Deutsche Forschungsgemeinschaft) (WA 1096/3-2), the Country of Baden-Württemberg (Landesforschungsschwerpunktprogramm (LFSP)), and the University of Ulm.

\section{References}

1 Ahima RS. Adipose tissue as an endocrine organ. Obesity (Silver Spring) 2006; 14 (Suppl 5): 242S-249S

2 Kershaw EE, Flier JS. Adipose tissue as an endocrine organ. J Clin Endocrinol Metab 2004; 89: 2548-2556

3 Flier JS. Obesity wars: molecular progress confronts an expanding epidemic. Cell 2004; 116: 337-350

4 Hauner $H$, Hochberg $Z$. Endocrinology of adipose tissue. Horm Metab Res 2002; 34: 605-606

5 Ailhaud G, Hauner H. Development of white adipose tissue. In: Bray, GA, Bouchard, C (eds). Handbook of obesity 2nd Ed. New York: Marcel Dekker, 2004;481-514

6 Fischer-Posovszky P, Tornqvist H, Debatin KM, Wabitsch M. Inhibition of death-receptor mediated apoptosis in human adipocytes by the insulin-like growth factor I (IGF-I)/IGF-I receptor autocrine circuit. Endocrinology 2004; 145: 1849-1859

7 Prins JB, O'Rahilly S. Regulation of adipose cell number in man. Clin Sci (Lond) 1997; 92: 3-11 
8 Della-Fera MA, Qian H, Baile CA. Adipocyte apoptosis in the regulation of body fat mass by leptin. Diabetes Obes Metab 2001; 3: 299-310

9 Wabitsch $M$. The acquisition of obesity: insights from cellular and genetic research. Proc Nutr Soc 2000; 59: 325-330

10 Hauner H, Entenmann G, Wabitsch M, Gaillard D, Ailhaud G, Negrel R, Pfeiffer EF. Promoting effect of glucocorticoids on the differentiation of human adipocyte precursor cells cultured in a chemically defined medium. J Clin Invest 1989; 84: 1663-1670

11 Petruschke $T$, Hauner $H$. Tumor necrosis factor-alpha prevents the differentiation of human adipocyte precursor cells and causes delipidation of newly developed fat cells. J Clin Endocrinol Metab 1993; 76: $742-747$

12 Lofgren P, Andersson I, Adolfsson B, Leijonhufvud BM, Hertel K, Hoffstedt J, Arner P. Long-term prospective and controlled studies demonstrate adipose tissue hypercellularity and relative leptin deficiency in the postobese state. J Clin Endocrinol Metab 2005; 90: 62076213

13 van Harmelen V, Skurk T, Rohrig K, Lee YM, Halbleib M, Aprath-Husmann I, Hauner $H$. Effect of BMI and age on adipose tissue cellularity and differentiation capacity in women. Int J Obes Relat Metab Disord 2003; 27: 889-895

14 Bluher M, Wilson-Fritch L, Leszyk J, Laustsen PG, Corvera S, Kahn CR. Role of insulin action and cell size on protein expression patterns in adipocytes. J Biol Chem 2004; 279: 31902-31909

15 Arner $P$. Human fat cell lipolysis: biochemistry, regulation and clinical role. Best Pract Res Clin Endocrinol Metab 2005; 19: 471-482

16 Farnier C, Krief S, Blache M, Diot-Dupuy F, Mory G, Ferre P, Bazin R. Adipocyte functions are modulated by cell size change: potential involvement of an integrin/ERK signalling pathway. Int J Obes Relat Metab Disord 2003; 27: 1178-1186

17 Jernas M, Palming J, Sjoholm K, Jennische E, Svensson PA, Gabrielsson $B G$, Levin M, Sjogren A, Rudemo M, Lystig TC, Carlsson B, Carlsson LM, Lonn $M$. Separation of human adipocytes by size: hypertrophic fat cells display distinct gene expression. Faseb J 2006; 20: 1540-1542

18 Hotamisligil GS, Shargill NS, Spiegelman BM. Adipose expression of tumor necrosis factor-alpha: direct role in obesity-linked insulin resistance. Science 1993; 259: 87-91

19 Weisberg SP, McCann D, Desai M, Rosenbaum M, Leibel RL, Ferrante $A W, J r$. Obesity is associated with macrophage accumulation in adipose tissue. J Clin Invest 2003; 112: 1796-1808

20 Curat CA, Miranville A, Sengenes C, Diehl M, Tonus C, Busse R, Bouloumie $A$. From blood monocytes to adipose tissue-resident macrophages: induction of diapedesis by human mature adipocytes. Diabetes 2004; 53: 1285-1292

21 Cancello R, Henegar C, Viguerie N, Taleb S, Poitou C, Rouault C, Coupaye M, Pelloux V, Hugol D, Bouillot JL, Bouloumie A, Barbatelli G, Cinti S, Svensson PA, Barsh GS, Zucker JD, Basdevant A, Langin D, Clement K. Reduction of macrophage infiltration and chemoattractant gene expression changes in white adipose tissue of morbidly obese subjects after surgery-induced weight loss. Diabetes 2005; 54: 2277-2286

22 Xu H, Barnes GT, Yang Q, Tan G, Yang D, Chou CJ, Sole J, Nichols A, Ross $J S$, Tartaglia $L A$, Chen $H$. Chronic inflammation in fat plays a crucial role in the development of obesity-related insulin resistance. J Clin Invest 2003; 112: 1821-1830

23 Manco M, Fernandez-Real JM, Equitani F, Vendrell J, Valera Mora ME, Nanni G, Tondolo V, Calvani M, Ricart W, Castagneto M, Mingrone G. Effect of massive weight loss on inflammatory adipocytokines and the innate immune system in morbidly obese women. J Clin Endocrinol Metab 2006, in press

24 Zhang Y, Proenca R, Maffei M, Barone M, Leopold L, Friedman JM. Positional cloning of the mouse obese gene and its human homologue. Nature 1994; 372: 425-432

25 Chen H, Charlat O, Tartaglia LA, Woolf EA, Weng X, Ellis SJ, Lakey ND, Culpepper J, Moore KJ, Breitbart RE, Duyk GM, Tepper RI, Morgenstern JP. Evidence that the diabetes gene encodes the leptin receptor: identification of a mutation in the leptin receptor gene in $\mathrm{db} / \mathrm{db}$ mice. Cell 1996; 84: 491-495

26 Lee GH, Proenca R, Montez JM, Carroll KM, Darvishzadeh JG, Lee JI, Friedman JM. Abnormal splicing of the leptin receptor in diabetic mice. Nature 1996; 379: 632-635

27 Tartaglia LA, Dembski M, Weng X, Deng N, Culpepper J, Devos R, Richards GJ, Campfield LA, Clark FT, Deeds J, Muir C, Sanker S, Moriarty A, Moore KJ, Smutko JS, Mays GG, Wool EA, Monroe CA, Tepper RI. Identification and expression cloning of a leptin receptor, OB-R. Cell 1995; 83: 1263-1271

28 Farooqi IS, Matarese G, Lord GM, Keogh JM, Lawrence E, Agwu C, Sanna V, Jebb SA, Perna F, Fontana S, Lechler RI, DePaoli AM, O'Rahilly S. Beneficial effects of leptin on obesity, T cell hyporesponsiveness, and neuroendo- crine/metabolic dysfunction of human congenital leptin deficiency. J Clin Invest 2002; 110: 1093-1103

29 Zelissen PM, Stenlof K, Lean ME, Fogteloo J, Keulen ET, Wilding J, Finer $N$, Rossner S, Lawrence E, Fletcher C, McCamish $M$. Effect of three treatment schedules of recombinant methionyl human leptin on body weight in obese adults: a randomized, placebo-controlled trial. Diabetes Obes Metab 2005; 7: 755-761

30 Howard JK, Cave BJ, Oksanen LJ, Tzameli I, Bjorbaek C, Flier JS. Enhanced leptin sensitivity and attenuation of diet-induced obesity in mice with haploinsufficiency of Socs3. Nat Med 2004; 10: 734-738

31 Mori $H$, Hanada $R$, Hanada $T$, Aki D, Mashima $R$, Nishinakamura $H$, Torisu T, Chien KR, Yasukawa H, Yoshimura A. Socs3 deficiency in the brain elevates leptin sensitivity and confers resistance to dietinduced obesity. Nat Med 2004; 10: 739-743

32 Gorden P, Park JY. The clinical efficacy of the adipocyte-derived hormone leptin in metabolic dysfunction. Arch Physiol Biochem 2006; 112: $114-118$

33 Bjorbaek C, Kahn BB. Leptin signaling in the central nervous system and the periphery. Recent Prog Horm Res 2004; 59: 305-331

34 Margetic S, Gazzola C, Pegg GG, Hill RA. Leptin: a review of its peripheral actions and interactions. Int J Obes Relat Metab Disord 2002; 26: $1407-1433$

35 Koerner A, Kratzsch J, Kiess W. Adipocytokines: leptin--the classical, resistin--the controversical, adiponectin--the promising, and more to come. Best Pract Res Clin Endocrinol Metab 2005; 19: 525-546

36 Bouret SG, Draper SJ, Simerly RB. Trophic action of leptin on hypothalamic neurons that regulate feeding. Science 2004; 304: 108-110

37 Scherer PE, Williams S, Fogliano M, Baldini G, Lodish HF. A novel serum protein similar to $\mathrm{C} 1 \mathrm{q}$, produced exclusively in adipocytes. J Biol Chem 1995; 270: 26746-26749

$38 \mathrm{Hu}$ E, Liang P, Spiegelman BM. AdipoQ is a novel adipose-specific gene dysregulated in obesity. J Biol Chem 1996; 271: 10697-10703

39 Maeda K, Okubo K, Shimomura I, Funahashi T, Matsuzawa Y, Matsubara $K$. cDNA cloning and expression of a novel adipose specific collagen-like factor, apM1 (AdiPose Most abundant Gene transcript 1). Biochem Biophys Res Commun 1996; 221: 286-289

40 Shapiro L, Scherer PE. The crystal structure of a complement-1q family protein suggests an evolutionary link to tumor necrosis factor Curr Biol 1998; 8: 335-338

41 Fain JN, Madan AK, Hiler ML, Cheema P, Bahouth SW. Comparison of the release of adipokines by adipose tissue, adipose tissue matrix, and adipocytes from visceral and subcutaneous abdominal adipose tissues of obese humans. Endocrinology 2004; 145: 2273-2282

42 Berg AH, Combs TP, Scherer PE. ACRP30/adiponectin: an adipokine regulating glucose and lipid metabolism. Trends Endocrinol Metab 2002; 13: 84-89

43 Crouch E, Persson A, Chang D, Heuser J. Molecular structure of pulmonary surfactant protein D (SP-D). J Biol Chem 1994; 269: 1731117319

44 McCormack FX, Pattanajitvilai S, Stewart J, Possmayer F, Inchley K, Voelker DR. The Cys6 intermolecular disulfide bond and the collagenlike region of rat SP-A play critical roles in interactions with alveolar type II cells and surfactant lipids. J Biol Chem 1997; 272: 27971-27979

45 Wong GW, Wang J, Hug C, Tsao TS, Lodish HF. A family of Acrp30/adiponectin structural and functional paralogs. Proc Natl Acad Sci USA 2004; 101: 10302-10307

46 Wang $Y, X u$ A, Knight C, Xu LY, Cooper GJ. Hydroxylation and glycosylation of the four conserved lysine residues in the collagenous domain of adiponectin. Potential role in the modulation of its insulin-sensitizing activity. J Biol Chem 2002; 277: 19521-19529

47 Pajvani UB, Du X, Combs TP, Berg AH, Rajala MW, Schulthess T, Engel J, Brownlee $M$, Scherer PE. Structure-function studies of the adipocyte-secreted hormone Acrp30/adiponectin. Implications fpr metabolic regulation and bioactivity. J Biol Chem 2003; 278: 90739085

48 Waki H, Yamauchi T, Kamon J, Ito Y, Uchida S, Kita S, Hara K, Hada Y, Vasseur F, Froguel P, Kimura S, Nagai R, Kadowaki T. Impaired multimerization of human adiponectin mutants associated with diabetes. Molecular structure and multimer formation of adiponectin. J Biol Chem 2003; 278: 40352-40363

49 Kadowaki T, Yamauchi T. Adiponectin and adiponectin receptors. Endocr Rev 2005; 26: 439-451

50 Fruebis J, Tsao TS, Javorschi S, Ebbets-Reed D, Erickson MR, Yen FT, Bihain BE, Lodish HF. Proteolytic cleavage product of $30-\mathrm{kDa}$ adipocyte complement-related protein increases fatty acid oxidation in muscle and causes weight loss in mice. Proc Natl Acad Sci USA 2001; 98: 2005-2010 
51 Yamauchi T, Kamon J, Ito Y, Tsuchida A, Yokomizo T, Kita S, Sugiyama T, Miyagishi M, Hara K, Tsunoda M, Murakami K, Ohteki T, Uchida S, Takekawa S, Waki H, Tsuno NH, Shibata Y, Terauchi Y, Froguel P, Tobe K, Koyasu S, Taira K, Kitamura T, Shimizu T, Nagai R, Kadowaki T. Cloning of adiponectin receptors that mediate antidiabetic metabolic effects. Nature 2003; 423: 762-769

52 Arita Y, Kihara S, Ouchi N, Takahashi M, Maeda K, Miyagawa J, Hotta K, Shimomura I, Nakamura T, Miyaoka K, Kuriyama H, Nishida M, Yamashita S, Okubo K, Matsubara K, Muraguchi M, Ohmoto Y, Funahashi T, Matsuzawa Y. Paradoxical decrease of an adipose-specific protein, adiponectin, in obesity. Biochem Biophys Res Commun 1999; 257: 79-83

53 Matsuzawa Y, Funahashi T, Kihara S, Shimomura I. Adiponectin and metabolic syndrome. Arterioscler Thromb Vasc Biol 2004; 24 : 29-33

54 Yamamoto Y, Hirose H, Saito I, Nishikai K, Saruta T. Adiponectin, an adipocyte-derived protein, predicts future insulin resistance: twoyear follow-up study in Japanese population. J Clin Endocrinol Metab 2004; 89: 87-90

55 Spranger J, Kroke A, Mohlig M, Bergmann MM, Ristow M, Boeing H, Pfeiffer AF. Adiponectin and protection against type 2 diabetes mellitus. Lancet 2003; 361: 226-228

56 Nakashima $R$, Kamei $N$, Yamane K, Nakanishi S, Nakashima A, Kohno N. Decreased total and high molecular weight adiponectin are independent risk factors for the development of type 2 diabetes in Japanese-americans. J Clin Endocrinol Metab 2006; 91: 3873-3877

57 Hara K, Horikoshi M, Yamauchi T, Yago H, Miyazaki O, Ebinuma H, Imai $Y$, Nagai R, Kadowaki T. Measurement of the high-molecular weight form of adiponectin in plasma is useful for the prediction of insulin resistance and metabolic syndrome. Diabetes Care 2006; 29 : 1357-1362

58 Lara-Castro C, Luo N, Wallace P, Klein RL, Garvey WT. Adiponectin multimeric complexes and the metabolic syndrome trait cluster. Diabetes 2006; 55: 249-259

59 Fisher FF, Trujillo ME, Hanif W, Barnett AH, McTernan PG, Scherer PE, Kumar S. Serum high molecular weight complex of adiponectin correlates better with glucose tolerance than total serum adiponectin in Indo-Asian males. Diabetologia 2005; 48: 1084-1087

60 Stumvoll M, Tschritter O, Fritsche A, Staiger H, Renn W, Weisser M, Machicao F, Haring $H$. Association of the T-G polymorphism in adiponectin (exon 2) with obesity and insulin sensitivity: interaction with family history of type 2 diabetes. Diabetes 2002; 51: 37-41

61 Vasseur F, Lepretre F, Lacquemant C, Froguel P. The genetics of adiponectin. Curr Diab Rep 2003; 3: 151-158

62 Kadowaki T, Yamauchi T, Kubota N, Hara K, Ueki K, Tobe K. Adiponectin and adiponectin receptors in insulin resistance, diabetes, and the metabolic syndrome. J Clin Invest 2006; 116: 1784-1792

63 Yamauchi T, Kamon J, Waki H, Terauchi Y, Kubota N, Hara K, Mori Y, Ide T, Murakami K, Tsuboyama-Kasaoka N, Ezaki O, Akanuma $Y$, Gavrilova O, Vinson C, Reitman ML, Kagechika H, Shudo K, Yoda M, Nakano Y, Tobe K, Nagai R, Kimura S, Tomita M, Froguel P, Kadowaki T. The fat-derived hormone adiponectin reverses insulin resistance associated with both lipoatrophy and obesity. Nat Med 2001; 7: 941-946

64 Berg AH, Combs TP, Du X, Brownlee M, Scherer PE. The adipocytesecreted protein Acrp30 enhances hepatic insulin action. Nat Med 2001; 7: 947-953

65 Mao X, Kikani CK, Riojas RA, Langlais P, Wang L, Ramos FJ, Fang $Q$ Christ-Roberts CY, Hong JY, Kim RY, Liu F, Dong LQ. APPL1 binds to adiponectin receptors and mediates adiponectin signalling and function. Nat Cell Biol 2006; 8: 516-523

66 Goldstein BJ, Scalia R. Adiponectin: a novel adipokine linking adipocytes and vascular function. J Clin Endocrinol Metab 2004; 89: 2563-2568

67 Ouchi N, Kihara S, Arita Y, Maeda K, Kuriyama H, Okamoto Y, Hotta K, Nishida M, Takahashi M, Nakamura T, Yamashita S, Funahashi T, Matsuzawa Y. Novel modulator for endothelial adhesion molecules: adipocyte-derived plasma protein adiponectin. Circulation 1999; 100: 2473-2476

68 Ouchi N, Kihara S, Arita Y, Okamoto Y, Maeda K, Kuriyama H, Hotta K, Nishida M, Takahashi M, Muraguchi M, Ohmoto Y, Nakamura T, Yamashita S, Funahashi T, Matsuzawa Y. Adiponectin, an adipocyte-derived plasma protein, inhibits endothelial NF-kappaB signaling through a cAMP-dependent pathway. Circulation 2000; 102: 1296-1301

69 Ouchi N, Kihara S, Arita Y, Nishida M, Matsuyama A, Okamoto Y, Ishigami M, Kuriyama H, Kishida K, Nishizawa $H$, Hotta K, Muraguchi $M$, Ohmoto Y, Yamashita S, Funahashi T, Matsuzawa Y. Adipocyte-derived plasma protein, adiponectin, suppresses lipid accumulation and class
A scavenger receptor expression in human monocyte-derived macrophages. Circulation 2001; 103: 1057-1063

70 Arita Y, Kihara S, Ouchi N, Maeda K, Kuriyama H, Okamoto Y, Kumada M, Hotta K, Nishida M, Takahashi M, Nakamura T, Shimomura I, Muraguchi M, Ohmoto Y, Funahashi T, Matsuzawa Y. Adipocyte-derived plasma protein adiponectin acts as a platelet-derived growth factor-BB-binding protein and regulates growth factor-induced common postreceptor signal in vascular smooth muscle cell. Circulation 2002; 105: 2893-2898

71 Tilg $H$, Moschen AR. Adipocytokines: mediators linking adipose tissue, inflammation and immunity. Nat Rev Immunol 2006; 6: 772-783

72 Wolf AM, Wolf D, Rumpold H, Enrich B, Tilg H. Adiponectin induces the anti-inflammatory cytokines IL-10 and IL-1RA in human leukocytes. Biochem Biophys Res Commun 2004; 323: 630-635

73 Yamaguchi N, Argueta JG, Masuhiro Y, Kagishita M, Nonaka K, Saito T, Hanazawa S, Yamashita Y. Adiponectin inhibits Toll-like receptor family-induced signaling. FEBS Lett 2005; 579: 6821-6826

74 Yokota T, Meka CS, Kouro T, Medina KL, Igarashi H, Takahashi M, Oritani K, Funahashi T, Tomiyama Y, Matsuzawa Y, Kincade PW. Adiponectin, a fat cell product, influences the earliest lymphocyte precursors in bone marrow cultures by activation of the cyclooxygenase-prostaglandin pathway in stromal cells. J Immunol 2003; 171: 5091-5099

75 Abel ED, Peroni O, Kim JK, Kim YB, Boss O, Hadro E, Minnemann T, Shulman GI, Kahn BB. Adipose-selective targeting of the GLUT4 gene impairs insulin action in muscle and liver. Nature 2001; 409: 729733

76 Gnudi L, Shepherd PR, Kahn BB. Over-expression of GLUT4 selectively in adipose tissue in transgenic mice: implications for nutrient partitioning. Proc Nutr Soc 1996; 55: 191-199

77 Yang Q Graham TE, Mody N, Preitner F, Peroni OD, Zabolotny JM, Kotani K, Quadro L, Kahn BB. Serum retinol binding protein 4 contributes to insulin resistance in obesity and type 2 diabetes. Nature 2005; 436: 356-362

78 Quadro L, Blaner WS, Salchow DJ, Vogel S, Piantedosi R, Gouras P, Freeman S, Cosma MP, Colantuoni V, Gottesman ME. Impaired retinal function and vitamin A availability in mice lacking retinol-binding protein. Embo J 1999; 18: 4633-4644

79 Kahn BB. Dietary regulation of glucose transporter gene expression: tissue specific effects in adipose cells and muscle. J Nutr 1994; 124: 1289-1295

80 Basualdo CG, Wein EE, Basu TK. Vitamin A (retinol) status of first nation adults with non-insulin-dependent diabetes mellitus. J Am Coll Nutr 1997; 16: 39-45

81 Abahusain MA, Wright J, Dickerson JW, de Vol EB. Retinol, alpha-tocopherol and carotenoids in diabetes. Eur J Clin Nutr 1999; 53: 630635

82 Munkhtulga L, Nakayama K, Utsumi N, Yanagisawa Y, Gotoh T, Omi $T$, Kumada M, Erdenebulgan B, Zolzaya K, Lkhagvasuren T, Iwamoto $S$. Identification of a regulatory SNP in the retinol binding protein 4 gene associated with type 2 diabetes in Mongolia. Hum Genet 2006, in press

83 Graham TE, Yang $Q$ Bluher M, Hammarstedt A, Ciaraldi TP, Henry RR, Wason CJ, Oberbach A, Jansson PA, Smith U, Kahn BB. Retinol-binding protein 4 and insulin resistance in lean, obese, and diabetic subjects. N Engl J Med 2006; 354: 2552-2563

84 Cho YM, Youn BS, Lee H, Lee N, Min SS, Kwak SH, Lee HK, Park KS. Plasma retinol-binding protein- 4 concentrations are elevated in human subjects with impaired glucose tolerance and type 2 diabetes. Diabetes Care 2006; 29: 2457-2461

85 Janke J, Engeli S, Boschmann M, Adams F, Bohnke J, Luft FC, Sharma $A M$, Jordan J. Retinol-binding protein 4 in human obesity. Diabetes 2006; 55: 2805-2810

86 Fukuhara A, Matsuda M, Nishizawa M, Segawa K, Tanaka M, Kishimoto K, Matsuki Y, Murakami M, Ichisaka T, Murakami H, Watanabe E, Takagi T, Akiyoshi M, Ohtsubo T, Kihara S, Yamashita S, Makishima M, Funahashi T, Yamanaka S, Hiramatsu R, Matsuzawa Y, Shimomura I. Visfatin: a protein secreted by visceral fat that mimics the effects of insulin. Science 2005; 307: 426-430

87 Samal B, Sun Y, Stearns G, Xie C, Suggs S, McNiece I. Cloning and characterization of the cDNA encoding a novel human pre-B-cell colony-enhancing factor. Mol Cell Biol 1994; 14: 1431-1437

88 Yang H, Lavu S, Sinclair DA. Nampt/PBEF/Visfatin: A regulator of mammalian health and longevity? Exp Gerontol 2006; 41: $718-726$

89 Rongvaux A, Shea RJ, Mulks MH, Gigot D, Urbain J, Leo O, Andris F. Pre-B-cell colony-enhancing factor, whose expression is up-regulated in activated lymphocytes, is a nicotinamide phosphoribosyl- 
transferase, a cytosolic enzyme involved in NAD biosynthesis. Eur J Immunol 2002; 32: 3225-3234

90 Wang T, Zhang X, Bheda P, Revollo JR, Imai S, Wolberger C. Structure of Nampt/PBEF/visfatin, a mammalian NAD+ biosynthetic enzyme. Nat Struct Mol Biol 2006; 13: 661-662

91 Kralisch S, Klein J, Lossner U, Bluher M, Paschke R, Stumvoll M, Fasshauer $M$. Hormonal regulation of the novel adipocytokine visfatin in 3T3-L1 adipocytes. J Endocrinol 2005; 185: R1-R8

92 Kralisch S, Klein J, Lossner U, Bluher M, Paschke R, Stumvoll M, Fasshauer $M$. Interleukin-6 is a negative regulator of visfatin gene expression in 3T3-L1 adipocytes. Am J Physiol Endocrinol Metab 2005; 289: E586-E590

93 Masuzaki H, Paterson J, Shinyama H, Morton NM, Mullins JJ, Seckl JR, Flier JS. A transgenic model of visceral obesity and the metabolic syndrome. Science 2001; 294: 2166-2170

94 Bahr V, Pfeiffer AF, Diederich S. The metabolic syndrome $\mathrm{X}$ and peripheral cortisol synthesis. Exp Clin Endocrinol Diabetes 2002; 110: $313-318$

95 Haider DG, Mittermayer F, Schaller G, Artwohl M, Baumgartner-Parzer $S M$, Prager G, Roden M, Wolzt M. Free fatty acids normalize a rosiglitazone-induced visfatin release. Am J Physiol Endocrinol Metab 2006, in press

96 Haider DG, Schaller G, Kapiotis S, Maier C, Luger A, Wolzt M. The release of the adipocytokine visfatin is regulated by glucose and insulin. Diabetologia 2006; 49: 1909-1914

97 Chen MP, Chung FM, Chang DM, Tsai JC, Huang HF, Shin SJ, Lee YJ. Elevated plasma level of visfatin/pre-B cell colony-enhancing factor in patients with type 2 diabetes mellitus. J Clin Endocrinol Metab 2006; 91: 295-299

98 Dogru T, Sonmez A, Tasci I, Bozoglu E, Yilmaz MI, Genc H, Erdem G, Gok M, Bingol N, Kilic S, Ozgurtas T, Bingol S. Plasma visfatin levels in patients with newly diagnosed and untreated type 2 diabetes mellitus and impaired glucose tolerance. Diabetes Res Clin Pract 2006, in press

99 Hammarstedt A, Pihlajamaki J, Rotter Sopasakis V, Gogg S, Jansson PA, Laakso $M$, Smith $U$. Visfatin is an adipokine, but it is not regulated by thiazolidinediones. J Clin Endocrinol Metab 2006; 91: 1181-1184

100 Berndt J, Kloting N, Kralisch S, Kovacs P, Fasshauer M, Schon MR, Stumvoll $M$, Bluher M. Plasma visfatin concentrations and fat depot-specific mRNA expression in humans. Diabetes 2005; 54: 2911-2916

101 Pagano C, Pilon C, Olivieri M, Mason P, Fabris R, Serra R, Milan G, Rossato M, Federspil G, Vettor R. Reduced plasma visfatin/pre-B cell colony-enhancing factor in obesity is not related to insulin resistance in humans. J Clin Endocrinol Metab 2006; 91: 3165-3170

102 Haider DG, Schindler K, Schaller G, Prager G, Wolzt M, Ludvik B. Increased plasma visfatin concentrations in morbidly obese subjects are reduced after gastric banding. J Clin Endocrinol Metab 2006; 91: 1578-1581

103 Haider DG, Pleiner J, Francesconi M, Wiesinger GF, Muller M, Wolzt M. Exercise training lowers plasma visfatin concentrations in patients with type 1 diabetes. J Clin Endocrinol Metab 2006, in press

104 Bottcher Y, Teupser D, Enigk B, Berndt J, Kloting N, Schon MR, Thiery J, Bluher M, Stumvoll M, Kovacs P. Genetic variation in the visfatin gene (PBEF1) and its relation to glucose metabolism and fat-depot-specific messenger ribonucleic acid expression in humans. J Clin Endocrinol Metab 2006; 91: 2725-2731

105 Curat CA, Wegner V, Sengenes C, Miranville A, Tonus C, Busse R, Bouloumie $A$. Macrophages in human visceral adipose tissue: increased accumulation in obesity and a source of resistin and visfatin. Diabetologia 2006; 49: 744-747

106 Van Harmelen V, Ariapart P, Hoffstedt J, Lundkvist I, Bringman S, Arner P. Increased adipose angiotensinogen gene expression in human obesity. Obes Res 2000; 8: 337-341

107 Umemura S, Nyui N, Tamura K, Hibi K, Yamaguchi S, Nakamaru M, Ishigami T, Yabana M, Kihara M, Inoue S, Ishii M. Plasma angiotensinogen concentrations in obese patients. Am J Hypertens 1997; 10: 629-633

108 Massiera F, Bloch-Faure M, Ceiler D, Murakami K, Fukamizu A, Gasc JM, Quignard-Boulange A, Negrel R, Ailhaud G, Seydoux J, Meneton $P$, Teboul $M$. Adipose angiotensinogen is involved in adipose tissue growth and blood pressure regulation. Faseb J 2001; 15: $2727-2729$

109 Skurk T, Lee YM, Hauner H. Angiotensin II and its metabolites stimulate PAI-1 protein release from human adipocytes in primary culture. Hypertension 2001; 37: 1336-1340
110 Skurk T, van Harmelen V, Blum WF, Hauner H. Angiotensin II promotes leptin production in cultured human fat cells by an ERK1/2-dependent pathway. Obes Res 2005; 13: 969-973

111 Skurk T, van Harmelen V, Hauner $H$. Angiotensin II stimulates the release of interleukin- 6 and interleukin- 8 from cultured human adipocytes by activation of NF-kappaB. Arterioscler Thromb Vasc Biol 2004; 24: 1199-1203

112 Ferder L, Inserra F, Martinez-Maldonado M. Inflammation and the metabolic syndrome: role of angiotensin II and oxidative stress. Curr Hypertens Rep 2006; 8: 191-198

113 Leiter $L A$, Lewanczuk $R Z$. Of the renin-angiotensin system and reactive oxygen species Type 2 diabetes and angiotensin II inhibition. Am J Hypertens 2005; 18: 121-128

114 Engeli S, Schling P, Gorzelniak K, Boschmann M, Janke J, Ailhaud G, Teboul M, Massiera F, Sharma AM. The adipose-tissue renin-angiotensin-aldosterone system: role in the metabolic syndrome? Int J Biochem Cell Biol 2003; 35: 807-825

115 Chung S, Lapoint K, Martinez K, Kennedy A, Boysen Sandberg M, McIntosh MK. Preadipocytes mediate lipopolysaccharide-induced inflammation and insulin resistance in primary cultures of newly differentiated human adipocytes. Endocrinology 2006; 147: 53405351

116 Fasshauer M, Klein J, Lossner U, Paschke R. Interleukin (IL)-6 mRNA expression is stimulated by insulin, isoproterenol, tumour necrosis factor alpha, growth hormone, and IL-6 in 3T3-L1 adipocytes. Horm Metab Res 2003; 35: 147-152

117 Do MS, Nam SY, Hong SE, Kim KW, Duncan JS, Beattie JH, Trayhurn P. Metallothionein gene expression in human adipose tissue from lean and obese subjects. Horm Metab Res 2002; 34: 348-351

118 Shoelson SE, Lee J, Goldfine AB. Inflammation and insulin resistance. J Clin Invest 2006; 116: 1793-1801

119 Boucher J, Castan-Laurell I, Daviaud D, Guigne C, Buleon M, Carpene C, Saulnier-Blache JS, Valet $P$. Adipokine expression profile in adipocytes of different mouse models of obesity. Horm Metab Res 2005; 37: 761-767

120 Janke J, Engeli S, Gorzelniak K, Feldpausch M, Heintze U, Bohnke J, Wellner M, Herse F, Lassalle P, Luft FC, Sharma AM. Adipose tissue and circulating endothelial cell specific molecule-1 in human obesity. Horm Metab Res 2006; 38: 28-33

121 Shoelson SE, Lee J, Yuan M. Inflammation and the IKK beta/I kappa B/NF-kappa B axis in obesity- and diet-induced insulin resistance. Int J Obes Relat Metab Disord 2003; 27 (Suppl 3): S49-S52

122 Aguirre V, Uchida T, Yenush L, Davis R, White MF. The c-Jun $\mathrm{NH}(2)-$ terminal kinase promotes insulin resistance during association with insulin receptor substrate- 1 and phosphorylation of Ser(307). J Biol Chem 2000; 275: 9047-9054

123 Hirosumi J, Tuncman G, Chang L, Gorgun CZ, Uysal KT, Maeda K, Karin $M$, Hotamisligil GS. A central role for JNK in obesity and insulin resistance. Nature 2002; 420: 333-336

124 Cai D, Yuan M, Frantz DF, Melendez PA, Hansen L, Lee J, Shoelson SE. Local and systemic insulin resistance resulting from hepatic activation of IKK-beta and NF-kappaB. Nat Med 2005; 11: 183-190

125 Akira S, Uematsu S, Takeuchi O. Pathogen recognition and innate immunity. Cell 2006; 124: 783-801

126 Ross SE, Hemati N, Longo KA, Bennett CN, Lucas PC, Erickson RL, MacDougald $O A$. Inhibition of adipogenesis by Wnt signalling. Science 2000; 289: 950-953

127 Longo KA, Wright WS, Kang S, Gerin I, Chiang SH, Lucas PC, Opp MR, MacDougald OA. Wnt10b inhibits development of white and brown adipose tissues. J Biol Chem 2004; 279: 35503-35509

128 Wright WS, Longo KA, Dolinsky VW, Gerin I, Kang S, Bennett CN, Chiang SH, Prestwich TC, Gress C, Burant CF, Susulic VS, MacDougald OA. Wnt10b inhibits obesity in ob/ob and agouti mice. Diabetes 2007; 56: 295-303

129 Christodoulides C, Scarda A, Granzotto M, Milan G, Dalla Nora E, Keogh J, De Pergola G, Stirling H, Pannacciulli N, Sethi JK, Federspil G, VidalPuig A, Farooqi IS, O'Rahilly S, Vettor R. WNT10B mutations in human obesity. Diabetologia 2006; 49: 678-684

130 Gustafson B, Smith U. Cytokines promote Wnt signaling and inflammation and impair the normal differentiation and lipid accumulation in 3T3-L1 preadipocytes. J Biol Chem 2006; 281: 9507-9516

131 Campfield LA, Smith FJ, Burn P. The OB protein (leptin) pathway - a link between adipose tissue mass and central neural networks. Horm Metab Res 1996; 28: 619-632 